\title{
A NEW SPECIES OF GENUS EUPHALANGIUM ROEWER (OPILIONES: PHALANGIDAE) FROM WESTERN HIMALAYAN REGION OF INDIA
}

\author{
N.P.I. Das and D.B. Bastawade
}

Zoological Survey of India, Western Regional Station, Pune, Maharashtra 411044, India

\begin{abstract}
A new species Euphalangium martensi is described from western Himalayan region with detail accounts and illustrations of external morphology and genitalia of both male and female. The morphometric data for legs I - IV (male \& female) are given in tabular form.

KeYwords

Euphalangium martensi sp. nov., genitalia, Himalaya, India, new description, Phalangiidae
\end{abstract}

Very few studies have been done on the Indian Himalayan phalangids. Some descriptions of Himalayan phalangids were done by Roewer (1912) in Nepal Himalaya. Since then, workers like Suzuki and Martens have confined their study to Nepal Himalaya.

The genus Euphalangium was raised by Roewer in 1911, with type Phalangium nordenskioeldi L. Koch. Roewer (1912) described a species Zachieus nepalicus, which was renamed as Euphalangium nepalicum by Martens (1973). According to Martens (1973) Opilio aborensis Roewer 1956 from Abor district, Assam (now Dibang Valley district, Arunanchal Pradesh) is likely to be a synonym to Euphalangium nepalicum, hence the genus has already been reported from India. Suzuki (1966) described two species E. panpema and E leuteum, which were then synonymised with Himalphalangium palpale (Roewer, 1956) by Martens from Nepal Himalaya for the first time. Martens (1973) along with recombination of Euphalangium nepalicum (Roewer, 1912) described new genus Himalphalangium on the basis of Opilio palpalis Roewer, 1956 and also described three new species as $H$. suzukii, $H$. dolpoense and H. unistriatum from Nepal Himalaya. He also synonymised Egaenus nepalensis Suzuki (1970) with Himalphalangium nepalense (Suzuki) establishing a new combination.

While studying the collections from the western Himalayan region, Himanchal Pradesh, India, received from Dr. R.M. Sharma, Officer-in-Charge, High Altitude Field Station, Zoological Survey of India, Solan, Himachal Pradesh, we came across some specimens belonging to the genus Euphalangium. The detail study of the specimens comparing with the only known species Euphalangium nepalicum (Roewer, 1912) from Western Himalaya, revealed that these belong to a new species, which we describe here as Euphalangium martensi sp. nov.

\section{Euphalangium martensi sp. nov.}

(Figs. 1-12)

\section{Material examined}

Holotype: Male, 17.ix.2000, Takchae, Kaza (above 3000m), Lahul Spiti, Himachal Pradesh, India, coll. Rahul Paliwal, Reg. No. 8830 (H.A.F.S., ZSI, Solan).

Paratypes: 6 males, 7 females. Same data as holotype

\section{Etymology}

The specific epithet is a patronym in honour of Jochen Martens who has extensively studied the Phalangid fauna of Nepal Himalaya.

\section{Description}

The species shows sexual dimorphism; the male and female being remarkably different in size and colour patterns. The female comparatively larger with body length of about $6.3 \mathrm{~mm}$ (Fig. 2) consists of carapace of about $1.3 \mathrm{~mm}$ and scutum of about $5.0 \mathrm{~mm}$ in length. The male specimen comparatively smaller than the female with body length $3.5 \mathrm{~mm}$ (Fig. 1) consists of carapace of about $1.1 \mathrm{~mm}$ and scutum of about $2.4 \mathrm{~mm}$ in length. Female carapace dark brown in colour with white patches, whereas light brown in colour with white patches on scutum. The carapace and scutum dark brown, appearing blackish and the posterior lateral bordering region of carapace and anterior lateral bordering region of scutum with white patches in the male. The pedipalp of female light brown in colour whereas that of male dark brown in colour.

Body soft, devoid of any large spine; carapace wider than length with minute spiny dentitions scattered on its surface, being more concentrated in the region in front of the occularium behind the supra-cheliceral lamellae. Occularium situated anteriorly in the ratio 0.9:1.3 in female and 0.8:1.1 ratio in male (Figs. $1 \& 2$ ). About five pairs of minute dentitions arranged in two rows above ocularium encircling the eyes (fig 4). Supra-cheliceral lamellae smooth without any projections (Fig. 3). Scutum provided with a row of very minute dentitions on each segment. Chelicerae three segmented; basal segment dorsally with few minute spiny bristles on anterior portion, middle segment dorsally and dorso-laterally with scattered spiny bristles; both movable and immovable fingers carinate with crenulations (Figs. $6 \&$ 7). Pedipalp trochanter with minute spines throughout the surface; femur with small pointed spines scattered on the ventral surface, the dorsal surface also provided with comparatively smaller spines; patella with few bristles on dorsal side; tibia with few minute pointed spines on ventral surface and bristles on dorsal side; tarsus with hairy bristles on its 

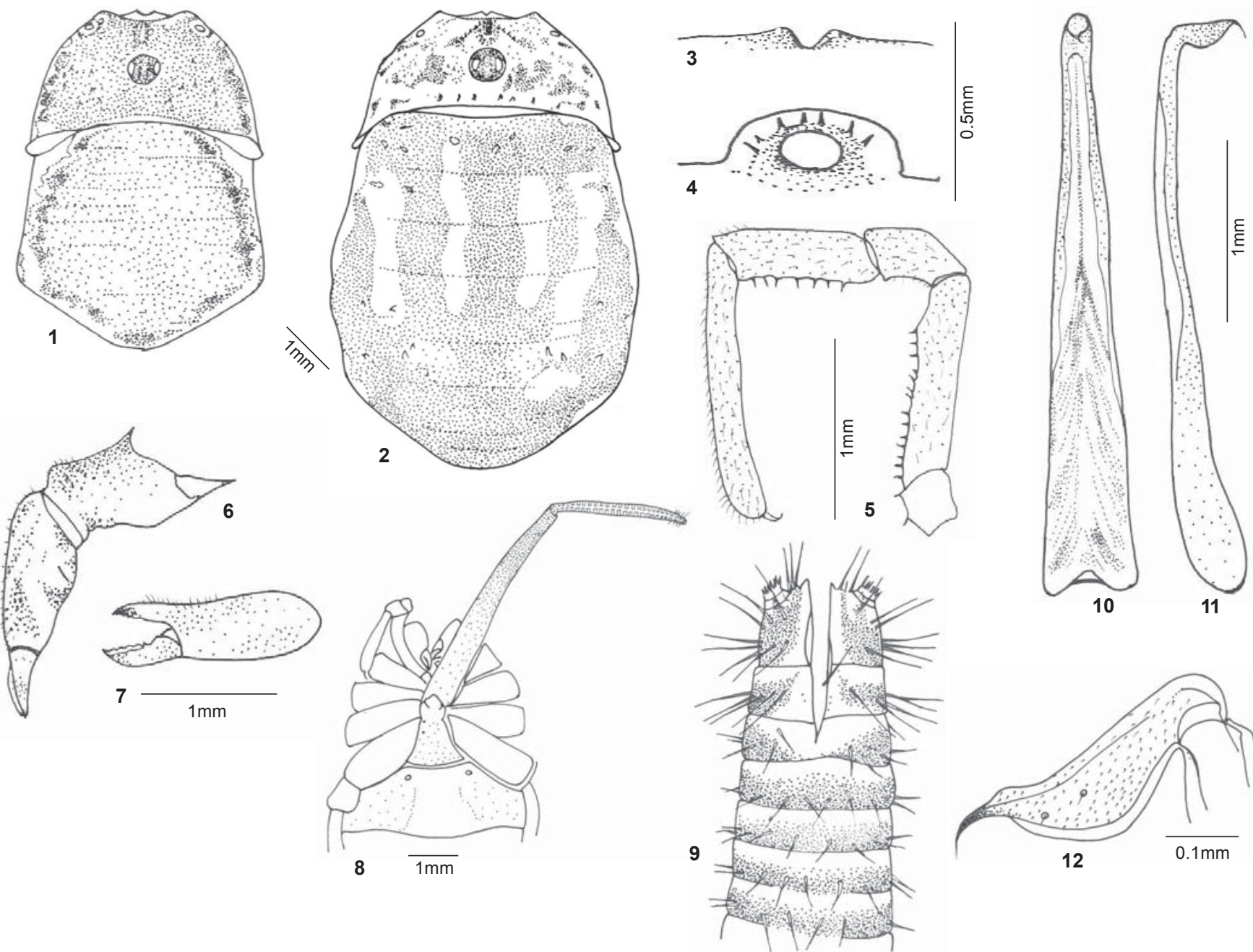

Figures 1-12. Euphalangium martensi sp. nov.

1 - Male, dorsal view; 2 - Female, dorsal view; 3 - Supra-cheliceral lamellae, dorsal view; 4 - Occular tubercle, lateral view; 5 - Pedipalp, lateral view; 6 - Chelicera, lateral view; 7 - Basal segment and fingers of chelicera, frontal view;

8 - Anterior portion of ventral side of female showing the expelled / ejected ovipositor; 9 - Ovipositor, dorsal view (anterior portion); 10 - Penis entire, dorsal view; 11 - Penis entire, lateral view; 12 - Glans of penis, lateral view.

surface more concentrated towards anterior dorsal tip; tarsal claw plain, pointed and curved (Fig. 5).

\section{Genitalia description}

Both the male and female genitalia of the species comparatively larger than that of other general palpatores.

Penis: Long with curved glans making about $90^{\circ}$ angle to the shaft. Shaft broader at base and narrower at tip. Allate not distinct (Figs. $10 \& 11$ ). The glans beset with minute spinules throughout its surface, of these two pairs of prominent small spines can be marked from other minute ones, arranged at lateral sides (Figs. 12).

Ovipositor: Much longer, typically dark bands on posterior half of each segment (Fig. 8). Slit sensilla extends up to third segment; first segment with six pairs of long spicules on dorsal side, remaining segments with five pairs of spicules arranged on dorsal side (Fig. 9). Seminal receptacle present in $4^{\text {th }}-5^{\text {th }}$ segmental region but much reduced to be noticed easily.

\section{Discussion}

The genus Euphalangium is represented by E. nepalicum (Roewer) from Himalaya by Martens as new combination. The described species $E$. martensi sp. nov. differs remarkably from E. nepalicum in both external morphology as well as genitalial structure. The pedipalp of E. martensi sp. nov. shows arrangement of simple spines without any tubercular projections as in E. nepalicum. The middle segment of chelicerae of $E$. martensi sp. nov., narrower and elongated, whereas that of $E$. nepalicum, stout and short. The male genitalia of the two species show difference, E. martensi sp. nov. beset with minute spinules throughout lateral surface of the glans of penis, whereas E.nepalicum shows no such minute spines. The arrangement of the two small prominent lateral spines in both the species also differ in respective position and size. 
Table 1. Measurements of Euphalangium martensi sp. nov. legs I - IV (in $\mathrm{mm}$ )

\begin{tabular}{llllllll}
\hline Male & \multicolumn{2}{l}{ Trochanter Femur } & Patella & Tibia & Mt-tarsus & Tarsus & Total \\
\hline Leg I & 0.6 & 4.3 & 1.2 & 4.0 & 4.0 & 7.4 & 21.5 \\
Leg II & 0.6 & 9.1 & 1.5 & 7.3 & 2.8 & 20.0 & 41.3 \\
Leg III & 0.6 & 3.5 & 0.9 & 3.8 & 4.8 & 6.0 & 19.6 \\
Leg IV & 0.6 & 5.0 & 0.9 & 5.0 & 5.7 & 10.2 & 27.4 \\
& & & & & & & \\
\hline Female & \multirow{2}{*}{ Trochanter } & Femur & Patella & Tibia & Mt-tarsus & Tarsus & Total \\
\hline \multirow{2}{*}{ Leg I } & 0.6 & 3.1 & 1.1 & 3.0 & 2.7 & 5.5 & 16.0 \\
Leg II & 0.6 & 5.5 & 1.3 & 5.3 & 2.5 & 16.3 & 31.5 \\
Leg III & 0.6 & 2.7 & 1.0 & 2.8 & 3.2 & 5.7 & 16.0 \\
Leg IV & 0.6 & 4.8 & 1.0 & 3.5 & 2.3 & 8.5 & 20.7 \\
\hline
\end{tabular}

\section{REFERENCES}

Martens, J. (1973). Opiliones aus dem Nepal Himalaya. II Phalangiidae und Sclerosomatidae (Arachnida). Senckenbergiana Biologica 54(1/3): 181-217.
Roewer, F.C. (1911). Uebersicht der genera der subfamilie der Phalangiini de Opiliones Palpatores nebst Beschreibung einiger newer Gattungen und Arten. Arch. Natg. Berlin 77 Bd1 Suppl- H 2: 1-106.

Roewer, F.C. (1912). Revision der Opiliones Palpatore (=Opiliones Plagiostheti) T1. II: Familie der Phalangiidae, (Subfamilien: Sclerosomini, Oligophini, Phalangiini) Hamburg Abh. Natw. Ver. 20 H 1: 1-295.

Suzuki, S (1966). Four phalangids from eastern Himalayas- Japan Journal of Zoology 15(2): 101-104.

\section{ACKnowledgement}

Authors fore mostly thank Dr. R.M. Sharma, Scientist-C and Officer-inCharge, High Altitude Zoolgy Field Station, Zoological Survey of India, Solan, Himachal Pradesh, for sending the phalangid specimens and allowing us to study and also permitting us for dissecting the specimen for genital studies. We are also indebted to Dr. J.R.B. Alfred, Director, Zoological Survey of India, Kolkata and Dr. A.S. Mahabal, Scientist-E and Officer-in-Charge, Zoological Survey of India, Western Regional Station, Pune for providing us the necessary laboratory and library facilities. We are also thankful to Mr. P.W. Garde, Sr. Artist, ZSI, WRS, Pune for preparation of the final diagrams.

\title{
FIRST RECORD OF GENUS CALLIHORMIUS ASHMEAD (HYMENOPTERA: BRACONIDAE) FROM INDIA, WITH DESCRIPTION OF A NEW SPECIES
}

\author{
S.M. Kurhade
}

Department of Zoology, New Arts, Commerce and Science College, Ahmednagar, Maharashtra 414001, India Corresponding Address: 'Riddhisiddhi', Vidya Colony, Opp. HUDCO, Pipeline Road, Ahmednagar, Maharashtra 414003, India

\begin{abstract}
A new hymenopteran of the family Braconidae, Callihormius orientalis sp. nov. has been described and illustrated. This represents the first record of this genus from India in IndoAustralian region.

\section{KEYWORDS}

Braconidae, Callihormius orientalis sp. nov., Hymenoptera, new description, new record
\end{abstract}

Ashmead (1900) erected the genus Callihormius with Pambolus bifasciatus Ashmead as its type species. Marsh (1966) revised this genus. This is a very small genus with only seven species described from Nearctic and Neotropical regions (Shenefelt \& Marsh, 1976).

In the present work Callihormius is recorded for the first time from India in Indo-Australian region. The key to the Nearctic species of Callihormius by Marsh (1966) has been followed and the new species is compared with Callihormius bajaensis Marsh (1966).

Types of this species are presently retained in the Entomological collection of Dr. Babasaheb Ambedkar Marathwada University, Aurangabad.

\section{Callihormius orientalis sp. nov.}

(Figs. 1-4)

Holotype: Female, 14.xi.1990, Ahmednagar, Maharashtra, India. On wing, coll. S.M. Kurhade, BAMU-SMK-101. Antenna, wings and legs mounted on slides and labelled as above.

Paratypes: 6 females, 14.xi.1990, Ahmednagar, Maharashtra, India. On wing, coll. S.M. Kurhade, BAMU-SMK-102-107.

\section{Etymology}

The species name is derived from the name of the region of its occurrence.

\section{Diagnosis}

Female: 3.8mm. (Fig. 1). Head (Fig. 2) 0.9 times as long as wide; vertex coriaceous, with few shallow punctures; ocellar region not raised, coriaceous; inter-ocellar distance 0.7 times the ocelloocular distance; frons coriaceous, concave; face convex, closely punctate, pubescent, 0.55 times as long as wide; clypeus small, triangular, 0.4 times as long as wide, punctate, pubescent; malar space $1.75 \mathrm{x}$ as long as basal width of mandible, coriaceous and punctate; mandible bidentate, stout, $1.75 \mathrm{x}$ as long as wide, with bristles; temple broad, coriaceous, with a few punctures, 0.45 times as wide as height of eye; eye bare, $2.15 \mathrm{x}$ as long as wide; occipital carina distinct. Antenna 2+26 segmented, long, 